\title{
Implementasi Google Cloud Messaging pada Sales Mobile Application
}

\author{
Christine Dewi ${ }^{1}$, Stephen Aprius Sutresno ${ }^{2}$ \\ Program Studi Teknik Informatika, Universitas Kristen Satya Wacana \\ Jl. Diponegoro 52-60, Salatiga 50711 \\ Email: ${ }^{1}$ christine.dewi@ staff.uksw.edu, ${ }^{2}$ st33ph3n@gmail.com
}

Masuk: 16 September 2015; Direvisi: 13 Oktober 2015; 21 Oktober 2015; Diterima: 22 Oktober 2015

\begin{abstract}
Sales forces are fundamental to determine the smooth process on the marketing firm engaged in sales. One of the companies in the Magelang engaged in sales is PT. Armada Internasional Motor. The car sales process in PT. Armada Internasional Motor still uses manual system. The use of the manual system needs a long time to process car sales to customers. Documents of vehicle order must be approved by several parties by providing signatures on the document. Therefore a new system is needed to solve the problem by building a sales application. The application is built by means of Location Based Service technology useful to help register the location and Google Cloud Messaging as a provider of the information from the server to clients. This research produces the application of a sales system based on mobile android platform that has already integrated various parties and can provide facilities to sales.
\end{abstract}

Keywords: Sales, Android, Location Based Service, Google Cloud Messaging.

\begin{abstract}
Abstrak. Karyawan yang memiliki posisi sebagai sales merupakan bagian penting dalam menentukan lancarnya alur proses pemasaran pada perusahaan yang bergerak dalam bidang penjualan. Sales di PT. Armada Internasional Motor masih menggunakan sistem manual dalam penjualan mobil kepada pelanggan. Penggunaan sistem yang manual tersebut membuat sales membutuhkan waktu yang lama untuk melakukan setiap penjualan mobil kepada pelanggan. Untuk itu dibutuhkan sistem baru yang dapat mengatasi masalah tersebut dengan membangun sebuah aplikasi sales. Aplikasi yang dibangun dengan menggunakan teknologi Location Based Service yang berguna membantu pencatatan lokasi dan menggunakan teknologi Google Cloud Messaging yang berguna sebagai pemberi informasi dari server kepada client. Penelitian ini menghasilkan aplikasi sistem sales berbasis mobile pada platform Android yang sudah terintegrasi baik dengan berbagai pihak dan dapat memberikan kemudahan kepada sales.
\end{abstract}

Kata Kunci: Sales, Android, Location Based Service, Google Cloud Messaging.

\section{Pendahuluan}

Masalah penjualan merupakan salah satu kegiatan yang sangat penting bagi setiap perusahaan. Oleh karena itu diperlukan suatu sistem secara efektif dan efisien sekaligus usaha yang dapat memberikan kemudahan dalam melaksanakan kegiatan perusahaan seiring dengan semakin maju dan berkembangnya teknologi sekarang ini. Seiring dengan perkembangan jaman, saat ini kita telah memasuki era dimana perangkat seluler merupakan kebutuhan yang wajib dimiliki oleh setiap orang untuk melakukan berbagai hal seperti komunikasi, bertukar informasi dan melakukan hal-hal lainnya. Salah satu sistem operasi perangkat seluler yang banyak digunakan dan perkembangannya sangat pesat saat ini adalah Android (Irsan, 2015). Android merupakan sebuah sistem operasi pada ponsel berbasis Linux yang mencakup sistem operasi dan middleware (Ichwan, dkk., 2013).

Pada perusahaan yang bergerak dalam bidang penjualan, karyawan yang memiliki posisi sebagai sales merupakan bagian penting dalam menentukan lancarnya alur proses pemasaran. Pada umumnya sistem kerja sales dalam melakukan penjualan barang kepada pelanggan yaitu dengan cara mengisi data pelanggan dan data barang yang akan dibeli pada 
sebuah dokumen yang kemudian ditandatangani oleh pelanggan. Dokumen ini berguna sebagai bukti persetujuan pembelian atau pemesanan barang oleh pelanggan.

Salah satu perusahaan yang bergerak dalam bidang penjualan yaitu PT. Armada Internasional Motor atau yang bisa disingkat dengan PT. AIM. Perusahaan ini merupakan salah satu anak perusahaan dari New Armada Group yang berpusat di Magelang dan mempunyai 10 cabang serta empat outlet. Di PT. AIM untuk karyawan yang memiliki posisi sebagai sales diharuskan membawa dokumen Surat Pesanan Kendaraan (SPK) dan dokumen data mobil. Dalam hal ini, dokumen SPK digunakan sebagai bukti pemesanan mobil oleh pelanggan yang di dalamnya terdapat data pelanggan, data mobil yang dipesan dan tanda tangan persetujuan dari beberapa pihak. Pihak-pihak yang harus memberikan persetujuan tersebut antara lain dari pihak Kepala Cabang, Administration Head, Supervisor Sales, dan pelanggan atau pemesan mobil. Untuk itu sales harus bertemu satu per satu dengan beberapa pihak tersebut. Namun untuk bertemu dengan beberapa pihak tersebut sering terjadi kendala seperti jarak antara sales dengan pihak yang jauh, juga kendala lain seperti pihak yang sedang memiliki urusan penting sehingga tidak dapat ditemui waktu itu juga. Beberapa kendala ini menyebabkan penjualan mobil kepada pelanggan menjadi tertunda dan kinerja sales menjadi kurang maksimal, penjualan mobil yang seharusnya dapat dilakukan dalam satu hari menjadi terhambat sekitar dua sampai lima hari. Selain itu, dokumen data mobil yang dibawa oleh sales setiap harinya harus diperbarui sesuai dengan data baru yang ada di perusahaan. Di dalam dokumen data mobil ini terdapat detail beserta stok semua mobil yang ada di gudang perusahaan. Namun dalam melakukan penjualan mobil kepada pelanggan, bisa terjadi tidak cocok antara stok yang ada di dokumen data mobil dengan stok yang ada di gudang perusahaan. Hal ini dapat menyebabkan penjualan mobil harus dibatalkan karena ketidaktersediaan stok di gudang perusahaan.

Dilihat dari sistem kerja sales yang masih manual tersebut, dapat menghambat kinerja sales dalam pencapaian target penjualan mobil yang telah ditetapkan oleh Supervisor Sales. Oleh karena itu, maka dilakukan perancangan dan pengimplementasian aplikasi sales berbasis mobile dengan platform Android dan menggunakan teknologi Location Based Service (LBS), service Google Cloud Messaging (GCM) dan teknologi SMS Gateway, yang bertujuan untuk memudahkan dan mempercepat sistem kerja sales. Sehingga sales dapat bekerja secara maksimal dalam pencapaian target penjualan mobil dan melancarkan alur proses pemasaran pada perusahaan. Aplikasi yang dibuat ini tidak membahas mengenai kecepatan bandwith internet, aplikasi hanya berjalan pada Android minimal versi 4.1 ke atas dan diterapkan hanya di PT. AIM Kota Magelang.

\section{Kajian Pustaka}

\subsection{Penelitian Sebelumnya}

Penelitian yang dilakukan sebelumnya oleh Pratama (2014) memanfaatkan teknologi dari Google Cloud Messaging (GCM) Service sebagai pengiriman message. Penelitian ini menghasilkan suatu aplikasi mobile commerce yang dirancang menggunakan konsep mobile commerce yang dimulai dari registrasi, pemesanan barang, hingga pada proses pembayaran dan pengiriman message singkat yang memanfaatkan teknologi Google Cloud Messaging (GCM) untuk pemberian informasi mengenai pemesanan yang terjadi dan informasi yang digunakan untuk mengkonfirmasi pembayaran dan pengiriman barang, objek yang digunakan adalah Toko Moachi Gemini, Semarang (Pratama, 2014).

Widodo (2012) membangun aplikasi jual beli online dengan memanfaatkan teknologi Google Cloud Messaging (GCM) Service sebagai pengiriman pesan singkat kepada pembeli untuk memberikan informasi mengenai proses transaksi yang sudah dilakukan. Pemesanan barang hingga pada proses pembayaran dan pengiriman pesan singkat yang memanfaatkan teknologi GCM untuk pemberian informasi mengenai pemesanan yang terjadi dan informasi yang digunakan untuk mengkonfirmasi pembayaran dan pengiriman barang

Berdasarkan penelitian-penelitian yang telah dilakukan terkait sales, LBS, dan GCM maka dilakukan penelitian yang membahas tentang perancangan dan pengimplementasian sales mobile application menggunakan teknologi location based service dan google cloud messaging. 
Aplikasi dibangun menggunakan teknologi LBS, GCM dan SMS Gateway. GCM adalah layanan yang membantu pengembang mengirim data dari server untuk aplikasi mereka pada perangkat Android (Irsan, 2015). Layanan ini menyediakan sebuah mekanisme sederhana yang tidak memakan banyak sumber daya CPU yang memungkinkan server untuk melakukan kontak terhadap aplikasi mobile pada sistem operasi Android agar aplikasi tersebut segera mengambil data terbaru pada server (Antonius, dkk., 2015). Service GCM ini diterapkan pada aplikasi dalam bentuk notifikasi atau pesan singkat yang dikirimkan oleh server. Notifikasi ini digunakan untuk memberikan informasi kepada sales tentang target yang harus dicapai per bulan dan memberikan informasi kepada Supervisor Sales, Administration Head dan Kepala Cabang ketika sales membuat SPK baru dan membutuhkan persetujuan dari pihak-pihak tersebut.

Untuk mendukung scalability maka digunakan teknologi web service sebagai solusi pertukaran data. Dengan memanfaatkan web service maka setiap platform baik aplikasi smartphone, web, maupun aplikasi desktop bisa memanggil method/fungsi yang diinginkan (Surendra, 2014). Sebagai pertukaran data digunakan JSON, format JSON tidak tergantung dengan bahasa pemrograman apapun, struktur JSON sederhana sehingga mudah diimplementasikan. JSON lebih sedikit membutuhkan space dan tidak perlu dituliskan dengan lengkap layaknya XML. Sehingga secara logika, proses pengolahannya (parsing) lebih cepat (Nugroho, dkk., 2013). LBS merupakan layanan informasi yang dapat diakses melalui perangkat mobile melalui jaringan selular dan memiliki kemampuan untuk memanfaatkan lokasi posisi perangkat mobile (Geoda \& Suprayogi, 2014). Teknologi LBS ini diterapkan pada aplikasi dalam pencatatan lokasi pada alamat pemesan saat terjadi pemesanan mobil kepada pelanggan. Pencatatan lokasi penjualan mobil berguna untuk memudahkan dalam pengantaran mobil ke alamat pemesan.

Aplikasi dibagi menjadi tiga yaitu aplikasi berbasis desktop dengan pengguna admin untuk mengelola data-data penjualan mobil, aplikasi berbasis mobile dengan pengguna sales untuk mengisikan data SPK baru dan melihat data mobil, aplikasi berbasis mobile dengan pengguna Supervisor Sales, Administration Head dan Kepala Cabang untuk memberikan persetujuan pada SPK tiap sales.

\section{Perancangan Sistem}

Pada tahap perancangan sistem menggunakan diagram UML yang berfungsi untuk menggambarkan prosedur dan proses kerja dari aplikasi. Use case diagram pada aplikasi ini dibagi menjadi dua, yang pertama untuk pengguna aplikasi berbasis desktop dan yang kedua untuk pengguna aplikasi berbasis mobile. Use case dari aplikasi desktop dapat dilihat pada Gambar 1, sedangkan use case dari aplikasi mobile dapat dilihat pada Gambar 2. Activity diagram untuk melakukan penambahan SPK baru oleh sales dapat dilihat pada Gambar 3.

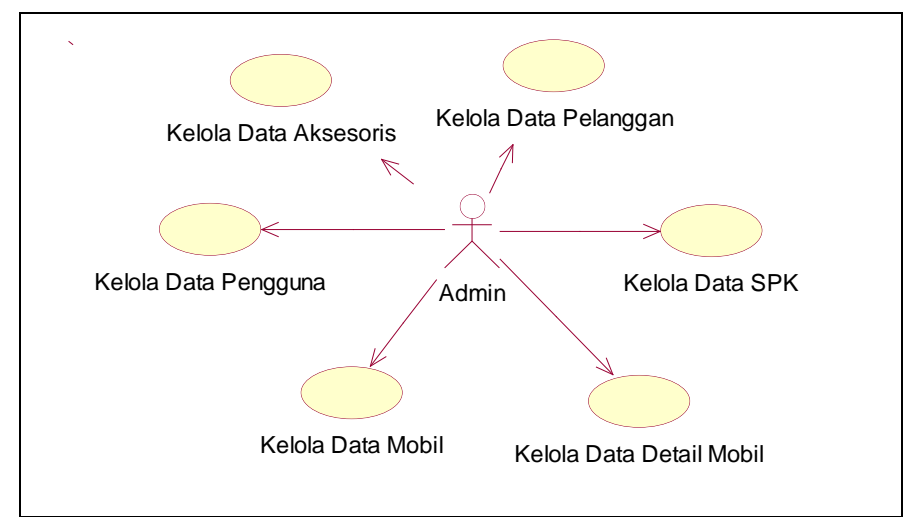

Gambar 1. Use Case Diagram Aplikasi Desktop 


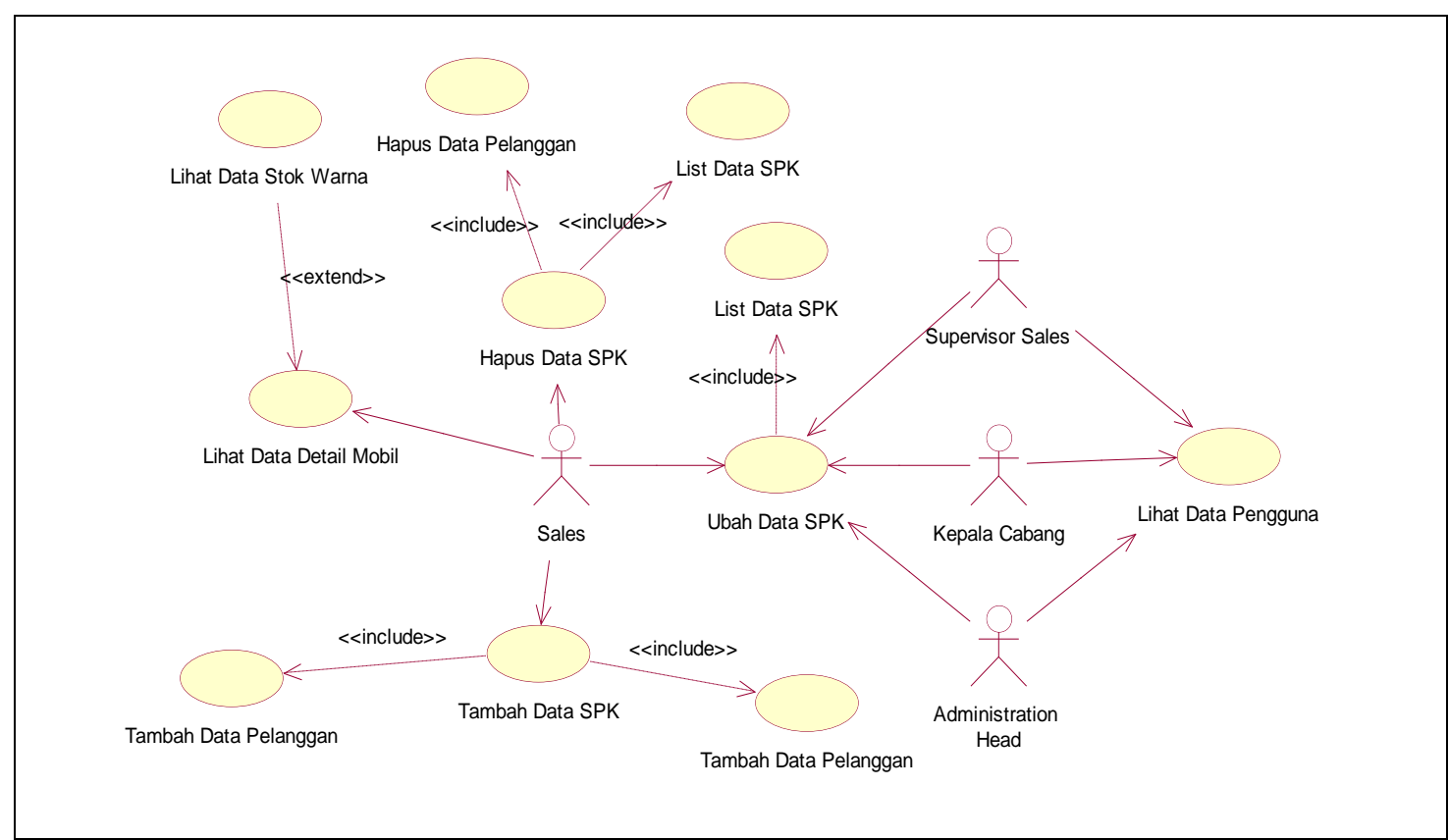

Gambar 2. Use Case Diagram Aplikasi Mobile

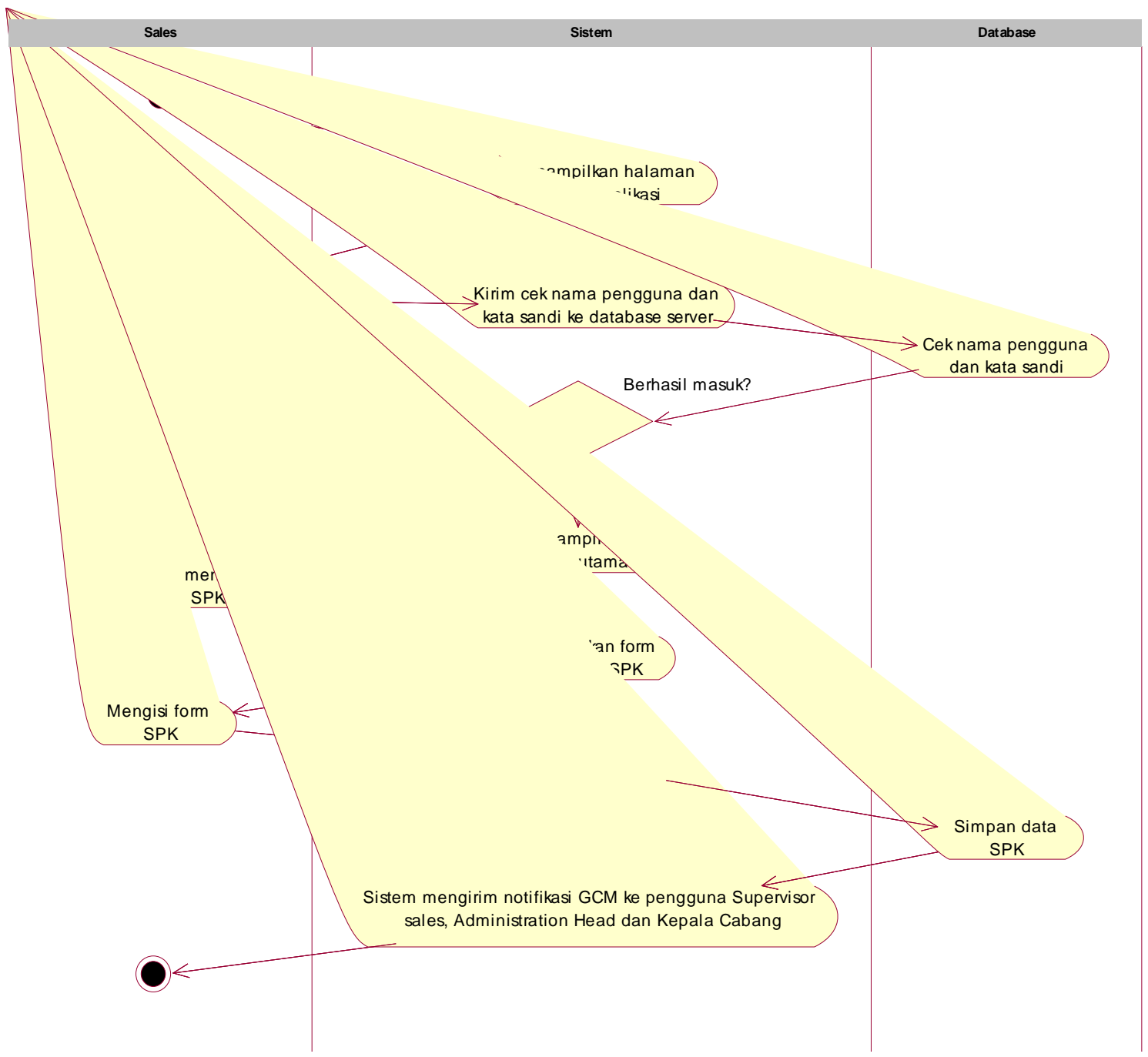

Gambar 3. Activity Diagram Penambahan SPK Baru oleh Sales. 
Pada Gambar 4 dapat dilihat terdapat tiga aplikasi dalam arsitektur ini yaitu dua aplikasi mobile dan satu aplikasi desktop. Aplikasi mobile diimplementasikan ke perangkat mobile dengan tujuan untuk digunakan oleh pengguna, yang terbagi menjadi empat pengguna yaitu pengguna sebagai sales, Supervisor Sales, Administration Head dan Kepala Cabang. Aplikasi desktop diimplementasikan pada laptop/PC dan ditujukan kepada admin untuk melihat dan mengelola data-data mengenai sales. Untuk dapat menjalankan kedua aplikasi, semua perangkat harus terhubung dengan koneksi internet. Dengan adanya internet, aplikasi mobile (pengguna sales) dapat mendapatkan lokasi menggunakan teknologi Location Based Service dan mengirim data ke database server melalui web service JSON. Saat data masuk ke database server, aplikasi desktop yang terhubung dengan modem dan berfungsi sebagai server SMS Gateway akan mengirimkan SMS ke handphone pelanggan. Bersamaan dengan proses tersebut, service Google Cloud Messaging akan berjalan secara otomatis dan mengirimkan notifikasi ke aplikasi mobile (pengguna selain sales).

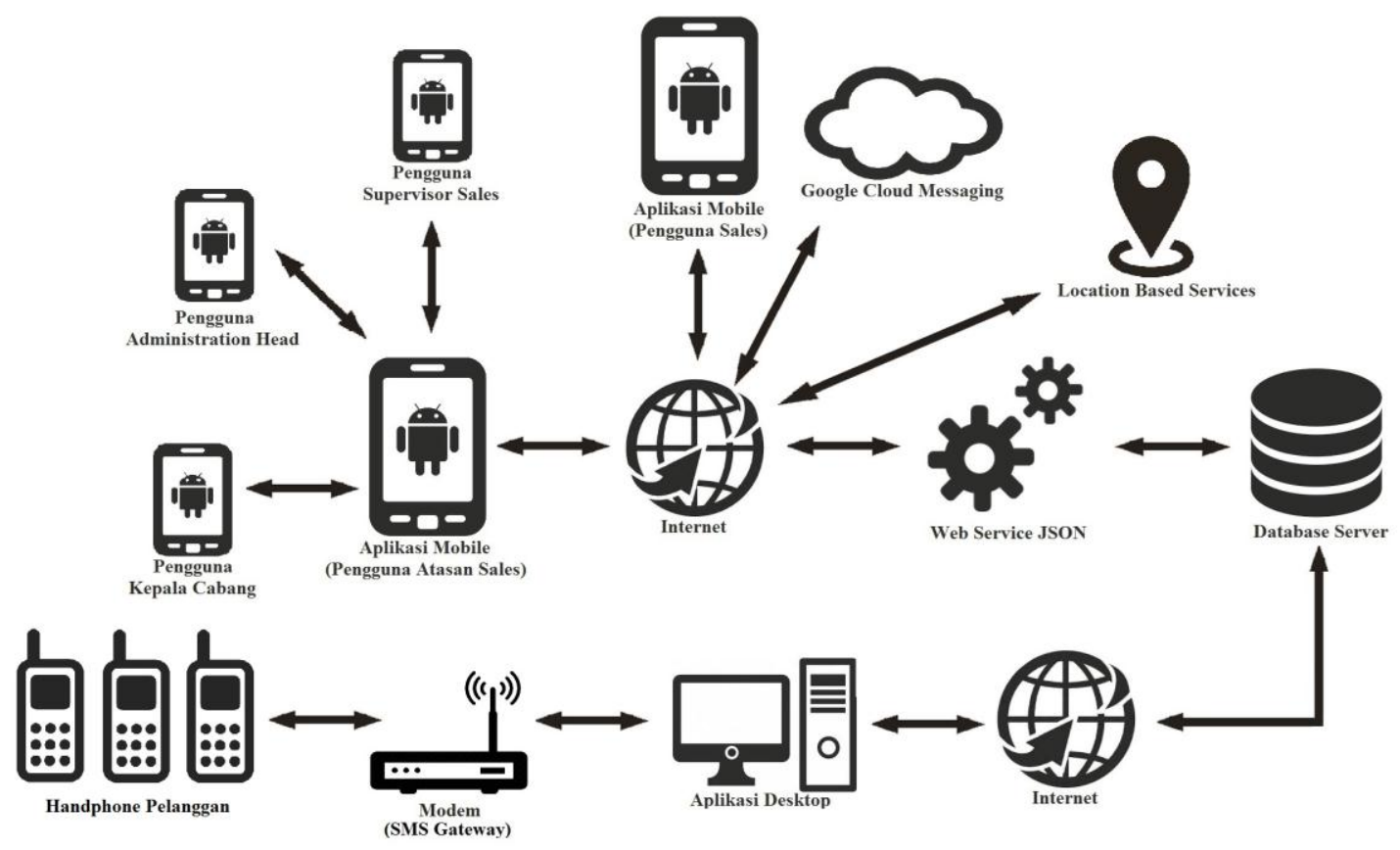

Gambar 4. Arsitektur Sistem

\section{Implementasi dan Pembahasan}

Penelitian ini menghasilkan tiga aplikasi yaitu dua aplikasi mobile dan satu aplikasi desktop. Pada aplikasi mobile diimplementasikan pada android platform sedangkan aplikasi desktop diimplementasikan pada komputer. Aplikasi mobile ditujukan kepada sales, Supervisor Sales, Administration Head dan Kepala Cabang yang bekerja di PT. AIM Magelang, sedangkan aplikasi desktop ditujukan kepada admin untuk mengelola data-data yang ada yaitu data pengguna, data pelanggan, data mobil dan data SPK.

Pada aplikasi mobile ini pengguna dapat membuat SPK baru, melihat data-data mobil beserta stok yang tersedia saat itu dan dapat melihat daftar SPK yang ingin disetujui. Menu SPK baru digunakan untuk membuat SPK baru untuk pemesanan mobil oleh pelanggan. Menu data mobil digunakan untuk melihat data-data mobil mengenai detail beserta stok yang tersedia. Menu daftar SPK digunakan untuk melihat seluruh SPK yang telah dibuat dan telah disetujui oleh pihak-pihak maupun belum disetujui. Menu keluar digunakan untuk keluar dari pengguna dan menuju ke halaman masuk.

Gambar 5 merupakan tampilan SPK baru. Pada tampilan ini terdapat beberapa form pengisian SPK, mulai dari data pemesan, data STNK, data instansi dan data mobil. Sales harus mengisi setiap field pada form yang telah disediakan untuk dapat melanjutkan ke form pengisian 
berikutnya. Setelah semua form diisi dan data SPK tersimpan dalam database server, maka server SMS Gateway akan mengirimkan SMS ke nomor Handphone pelanggan/pemesan mobil yang terlihat pada Gambar 6. Pada SMS terlihat merek dan model dari mobil yang dipesan oleh pelanggan. Setelah dilakukan konfirmasi oleh pelanggan maka SPK dapat dibuat dan diproses ke tahap selanjutnya.

Kode 1 merupakan Penggalan Kode Program fungsi pada aplikasi desktop yang digunakan juga sebagai server dari SMS Gateway. Pertama akan dilakukan pengambilan nomor yang sebelumnya dicek terlebih dahulu di database dari semua SMS yang diterima oleh modem. Setelah itu akan dikirim SMS kembali untuk konfirmasi pemesanan mobil ke nomor handphone pelanggan. Bersamaan dengan proses pengiriman SMS yang terlihat pada Gambar 6, service GCM juga akan mengirimkan notifikasi kepada pengguna Supervisor Sales, Administration Head dan Kepala Cabang.

Kode 1. Penggalan Kode Program SMS Gateway untuk Kirim SMS

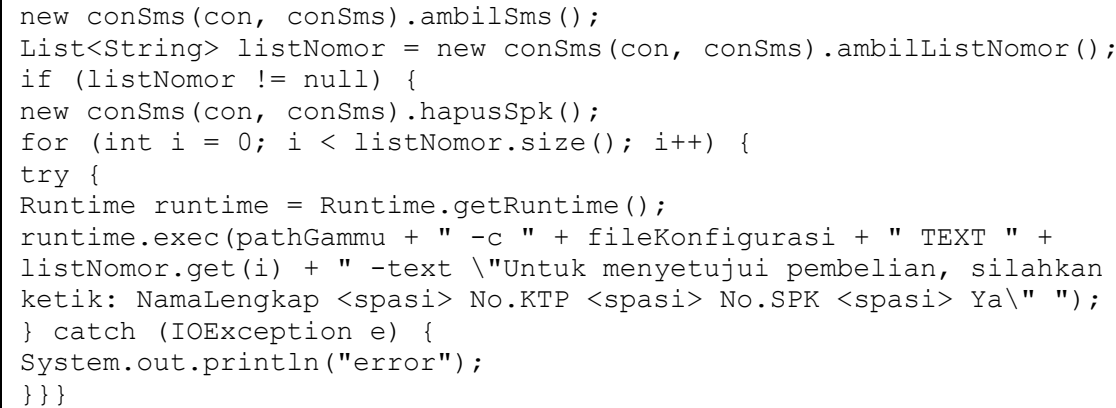

Kode 2 merupakan penggalan kode program fungsi $P H P$ pada aplikasi mobile yang digunakan untuk mengirimkan notifikasi. Pada fungsi $P H P$ ini dapat dilihat diperlukan Google API Key, Id GCM dan isi pesan dalam melakukan proses pengiriman notifikasi. Id GCM merupakan Id bersifat unique per device dan didapatkan melalui pendaftaran device ke server GCM. Id GCM ini yang nantinya digunakan sebagai tujuan/lokasi pengiriman notifikasi.

Kode 2. Penggalan Kode Program GCM untuk Kirim Notifikasi

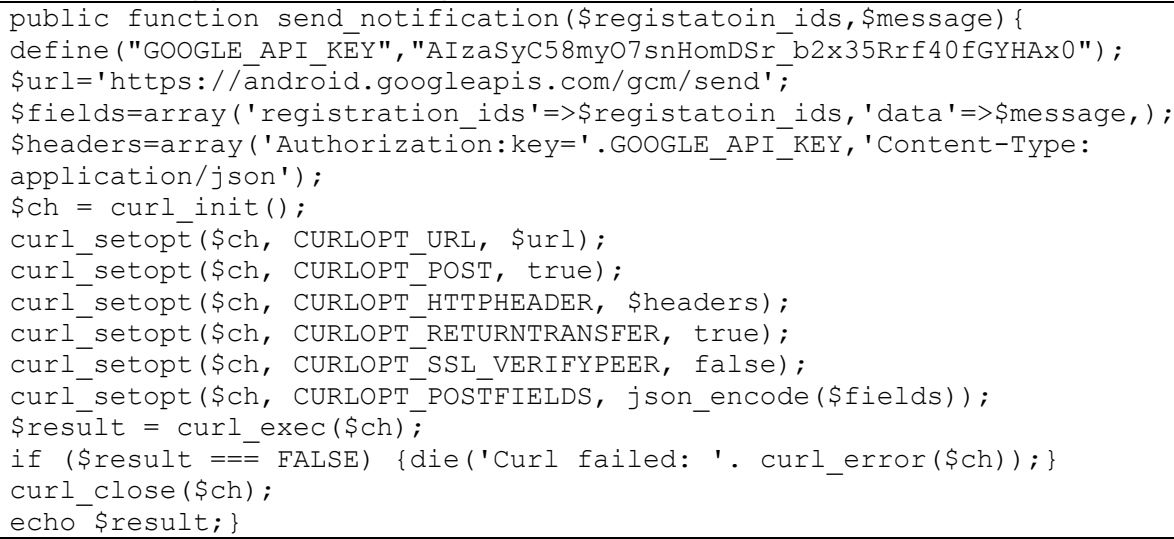

Gambar 7 merupakan tampilan lokasi pada alamat pemesan mobil. Tampilan ini dapat dilihat oleh pengguna Supervisor Sales, Administration Head dan Kepala Cabang pada saat melihat detail di daftar persetujuan SPK. Tampilan ini menggunakan teknologi LBS, yang dimanfaatkan untuk penyimpanan lokasi pada alamat pemesan di database server saat terjadi pemesanan mobil dan dimanfaatkan juga untuk menampilkan gambar sebuah peta dengan lokasi yang telah disimpan di database server. 


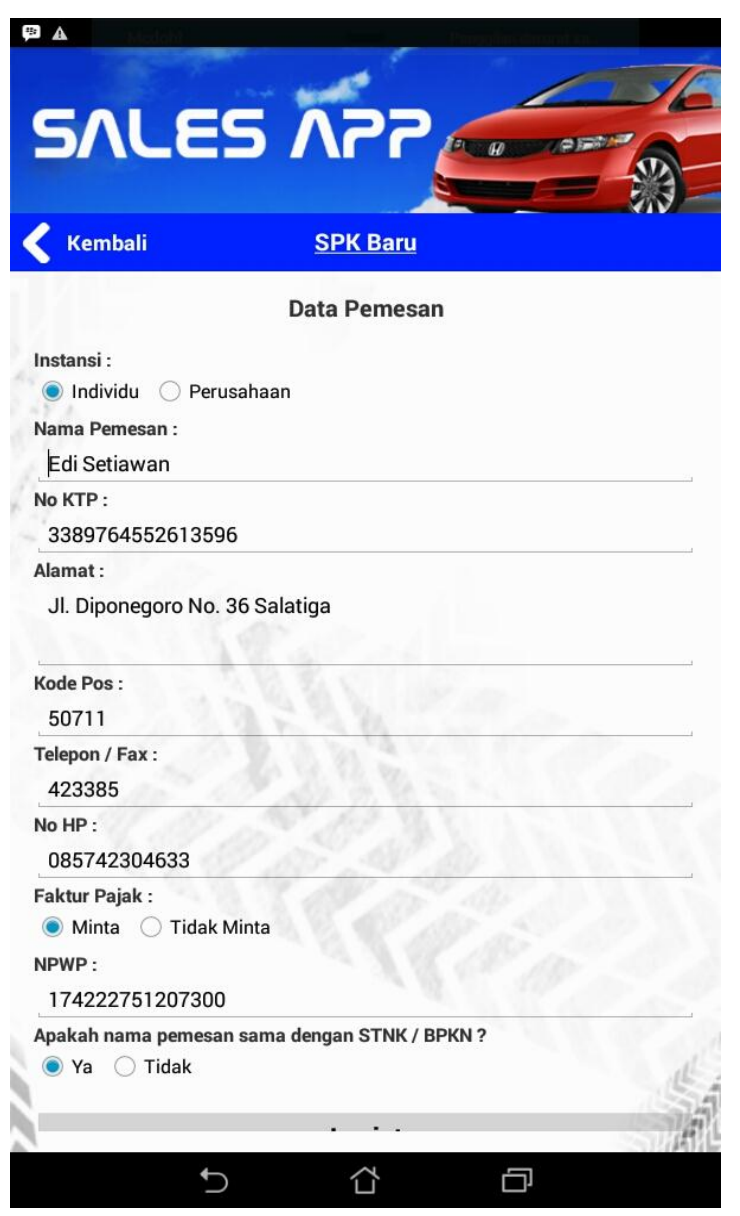

Gambar 5. Tampilan SPK Baru
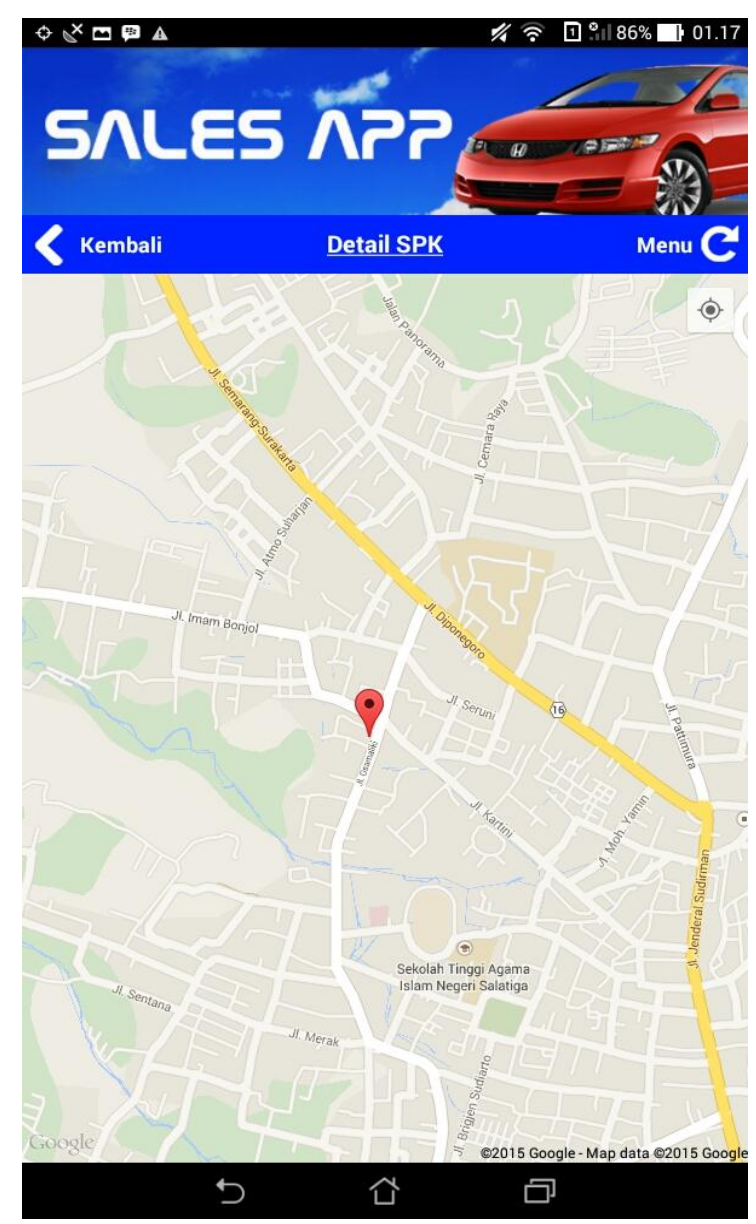

Gambar 7. Tampilan Lokasi pada Alamat Pemesan Mobil

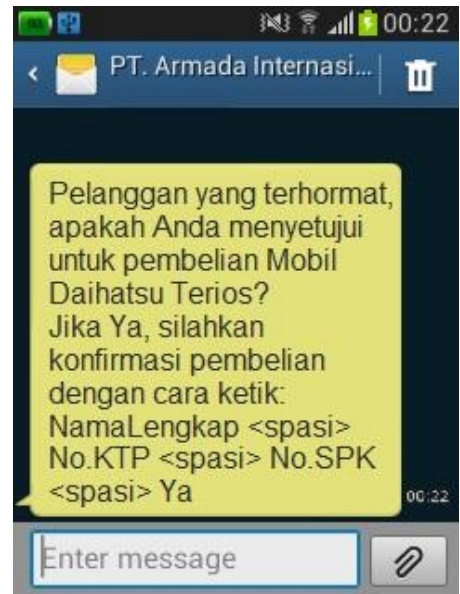

Gambar 6. Tampilan SMS pada Handphone Pelanggan

Kode 3 merupakan fungsi pada aplikasi mobile yang digunakan untuk menampilkan lokasi dari alamat pemesan mobil. Dalam fungsi ini diperlukan beberapa pengaturan terlebih dahulu seperti tipe peta yang akan ditampilkan, rotasi dan pembesar peta. Setelah itu ditentukan alamat yang kemudian dipasang sebuah penanda/marker pada peta tersebut sebagai penunjuk lokasi. 


\section{Kode 3. Penggalan Kode Program LBS untuk Menampilkan Lokasi}

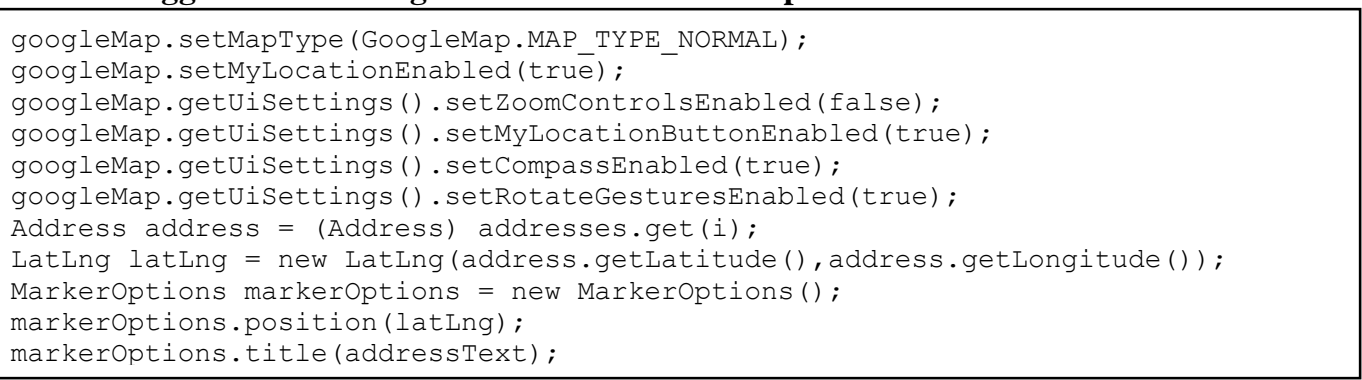

\section{Pengujian Aplikasi}

Pengujian aplikasi dilakukan dengan menguji fungsi-fungsi dari aplikasi yang telah dibuat untuk mencari kesalahan/bug pada sistem. Pengujian alpha adalah pengujian aplikasi yang dilakukan oleh pembuat aplikasi dan orang-orang yang ikut membantu dalam pembuatan. Pengujian alpha menggunakan metode blackbox yaitu pengujian fungsi-fungsi aplikasi secara langsung tanpa memperhatikan alur eksekusi program. Pengujian ini dilakukan dan sesuai yang diharapkan. Hasil pengujian dapat dilihat pada Tabel 1.

Tabel 1. Hasil Pengujian Alpha Aplikasi Desktop dan Mobile

\begin{tabular}{|c|c|c|c|c|c|}
\hline No & Fungsi yang diuji & Kondisi & $\begin{array}{l}\text { Output yang } \\
\text { diharapkan }\end{array}$ & $\begin{array}{c}\text { Output yang } \\
\text { dihasilkan sistem } \\
\end{array}$ & $\begin{array}{c}\text { Status } \\
\text { Pengujian }\end{array}$ \\
\hline 1 & Masuk aplikasi & $\begin{array}{l}\text { Nama pengguna dan kata sandi } \\
\text { benar } \\
\text { Nama pengguna dan kata sandi } \\
\text { salah maupun kosong }\end{array}$ & $\begin{array}{l}\text { Sukses masuk aplikasi } \\
\text { Gagal masuk aplikasi }\end{array}$ & $\begin{array}{l}\text { Sukses masuk aplikasi } \\
\text { Gagal masuk aplikasi }\end{array}$ & Valid \\
\hline 2 & $\begin{array}{l}\text { Tambah data } \\
\text { mobil }\end{array}$ & $\begin{array}{l}\text { Form diisi dengan benar } \\
\text { Form diisi beberapa atau kosong }\end{array}$ & $\begin{array}{l}\text { Sukses tambah data } \\
\text { Gagal tambah data }\end{array}$ & $\begin{array}{l}\text { Sukses tambah data } \\
\text { Gagal tambah data }\end{array}$ & Valid \\
\hline 3 & Ubah data mobil & Form diisi dengan benar & Sukses ubah data & Sukses ubah data & Valid \\
\hline 4 & Hapus data mobil & Data yang akan dihapus dipilih & Sukses hapus data & Sukses hapus data & Valid \\
\hline 5 & Tambah data SPK & $\begin{array}{l}\text { Form diisi dengan benar } \\
\text { Form diisi beberapa atau kosong }\end{array}$ & $\begin{array}{l}\text { Sukses tambah data } \\
\text { Gagal tambah data }\end{array}$ & $\begin{array}{l}\text { Sukses tambah data } \\
\text { Gagal tambah data } \\
\end{array}$ & Valid \\
\hline 8 & $\begin{array}{l}\text { Tambah data } \\
\text { aksesoris }\end{array}$ & $\begin{array}{l}\text { Form diisi dengan benar } \\
\text { Form diisi beberapa atau kosong }\end{array}$ & $\begin{array}{l}\text { Sukses tambah data } \\
\text { Gagal tambah data }\end{array}$ & $\begin{array}{l}\text { Sukses tambah data } \\
\text { Gagal tambah data }\end{array}$ & Valid \\
\hline 11 & Tampil data mobil & & Sukses tampil data & Sukses tampil data & Valid \\
\hline 12 & Tampil data SPK & & Sukses tampil data & Sukses tampil data & Valid \\
\hline 13 & $\begin{array}{l}\text { Tampil data } \\
\text { aksesoris }\end{array}$ & & Sukses tampil data & Sukses tampil data & Valid \\
\hline 14 & $\begin{array}{l}\text { Kirim SMS dari } \\
\text { Modem ke nomor } \\
\text { HP }\end{array}$ & Data SPK baru masuk & Sukses kirim SMS & Sukses kirim SMS & Valid \\
\hline 15 & $\begin{array}{l}\text { Simpan lokasi } \\
\text { penjualan mobil }\end{array}$ & Tambah data SPK berhasil & Sukses tambah data & Sukses tambah data & Valid \\
\hline 16 & $\begin{array}{l}\text { Tampil lokasi } \\
\text { penjualan mobil }\end{array}$ & $\begin{array}{l}\text { Data SPK yang dilihat lokasinya } \\
\text { dipilih }\end{array}$ & Sukses tampil data & Sukses tampil data & Valid \\
\hline 17 & $\begin{array}{l}\text { Pengujian Fitur } \\
\text { GCM }\end{array}$ & Tambah data SPK berhasil & Sukses tampil data & Sukses tampil data & Valid \\
\hline
\end{tabular}

Berdasarkan pengujian yang dilakukan pada aplikasi desktop dan mobile dapat dilihat status pengujian dari setiap fungsi valid, maka disimpulkan bahwa aplikasi ini berjalan dengan baik dan sesuai yang diharapkan. Untuk pengujian GCM dapat disimpulkan bahwa provider seluler berpengaruh terhadap pengiriman notifikasi, karena kinerja dari GCM itu sendiri sangat bergantung terhadap kualitas sinyal dari provider seluler, semakin bagus kualitas sinyal suatu provider maka semakin cepat notifikasi dikirimkan.

Pengujian beta dilakukan dengan menggunakan kuesioner, yaitu dengan membagikan kuesioner kepada sample user. Sample user terdiri dari 10 orang karyawan yang bekerja di PT. AIM Kota Magelang dengan kedudukan yang berbeda, yaitu satu orang Kepala Cabang, satu 
orang Administration Head, satu orang Supervisor Sales dan tujuh orang sales. Pengujian beta dapat dilihat pada Tabel 2.

Tabel 2. Hasil Pengujian Beta Aplikasi Desktop dan Mobile

\begin{tabular}{|c|c|c|c|c|c|c|}
\hline No & Pernyataan & STS & TS & $\mathbf{C S}$ & $\mathbf{S}$ & SS \\
\hline \multirow[t]{2}{*}{1} & Aplikasi dalam sistem ini mudah untuk digunakan & 0 & 1 & 4 & 5 & 0 \\
\hline & Presentase $(\%)$ & 0 & 10 & 40 & 50 & 0 \\
\hline \multirow[t]{2}{*}{2} & Menu-menu pada aplikasi ini mudah dipahami & 0 & 0 & 3 & 5 & 2 \\
\hline & Presentase $(\%)$ & 0 & 0 & 30 & 50 & 20 \\
\hline \multirow[t]{2}{*}{3} & $\begin{array}{l}\text { Melalui aplikasi ini semua dokumentasi mengenai data mobil dan SPK dapat diolah dan } \\
\text { tersimpan dengan baik dan aman oleh sistem }\end{array}$ & 0 & 2 & 5 & 3 & 0 \\
\hline & Presentase (\%) & & 20 & 50 & 30 & \\
\hline \multirow[t]{2}{*}{4} & $\begin{array}{l}\text { Aplikasi ini mempermudah dan mempercepat kinerja sales dalam melakukan penjualan } \\
\text { mobil kepada pelanggan }\end{array}$ & 0 & 0 & 5 & 3 & 2 \\
\hline & Presentase $(\%)$ & & & 50 & 30 & \\
\hline \multirow[t]{2}{*}{5} & $\begin{array}{l}\text { Aplikasi ini bermanfaat untuk digunakan oleh karyawan di PT. Armada Internasional } \\
\text { Motor kota Magelang }\end{array}$ & 0 & 0 & 6 & 1 & 3 \\
\hline & Presentase (\%) & & & 60 & 10 & \\
\hline
\end{tabular}

Setelah semua jawaban diketahui maka yang dilakukan adalah menghitung presentase jawaban responden yang telah mengisi kuesioner. Perhitungan dilakukan menggunakan skala Likert, di mana masing-masing jawaban diberi skor satu hingga lima dengan penjelasan sebagai berikut: Sangat Tidak Setuju (STS) $=0$, Tidak Setuju $(T S)=3$, Cukup Setuju $(C S)=23$, Setuju $(\mathrm{S})=17$, Sangat Setuju $(\mathrm{SS})=7$.

\section{Kesimpulan}

Penelitian ini menghasilkan aplikasi sales. Setelah dianalisis sistem aplikasinya dapat ditarik beberapa kesimpulan, yaitu aplikasi ini membantu mempercepat dan mempermudah kinerja sales yang bekerja di PT. AIM Kota Magelang dalam menangani penjualan mobil kepada pelanggan. Sales tidak perlu lagi membawa dokumen SPK dan data mobil namun hanya perlu membawa device Android yang telah terinstal aplikasi ini dan terkoneksi dengan internet. Pengecekan stok mobil dapat dilakukan secara online dan cocok dengan stok yang ada di gudang perusahaan saat itu. Sales tidak perlu lagi mendatangi pihak Supervisor Sales, Administration Head dan Kepala Cabang untuk memberikan persetujuan pada data SPK. Sistem akan secara langsung mengirimkan data SPK ke pihak-pihak tersebut untuk dapat disetujui secara online berupa checklist, kemudian sistem juga akan menjalankan service GCM yang memberikan layanan berupa notifikasi ketika data SPK tersebut dikirim oleh sales maupun telah disetujui oleh pihak-pihak tersebut. Pencatatan lokasi pada alamat pemesan oleh teknologi LBS pada saat terjadinya pemesanan mobil juga akan tercatat oleh sistem, sehingga nantinya dapat digunakan untuk memudahkan dalam mengantarkan mobil ke alamat pemesan. Selain itu, data mobil dan data SPK dapat diolah dan tersimpan dengan baik dan aman oleh sistem. Aplikasi ini membantu sales dalam meningkatkan kinerjanya dalam pencapaian target penjualan mobil.

\section{Referensi}

Antonius, Alvin., Dedy, Triyanto., \& Ruslianto, Ikhwan. 2015. Penerapan Pengolahan Citra Dengan Metode Adaptive Motion Detection Algorithm Pada Sistem Kamera Keamanan Dengan Push Notification Ke Smartphone Android. Jurnal Coding Sistem Komputer Untan, III(2), pp.54-65.

Geoda, G. P., \& Suprayogi, Andri. 2014. Pembuatan Aplikasi Sistem Informasi Geografis Kampus Universitas Diponegoro Berbasis Android. Jurnal Geodasi Undip, IV(3), pp.87-95.

Ichwan, Muhammad., Husada, Milda Gustiana., \& Rasyid, M. Iqbal Ar. 2013. Pembangunan Prototipe Sistem Pengendalian Peralatan Listrik Pada Platform Android. Jurnal Informatika, IV(1), pp.13-25.

Irsan, Muhammad. 2015. Rancang Bangun Aplikasi Mobile Notifikasi Berbasis Android Untuk Mendukung Kinerja Di Instasi Pemerintah. Jurnal Sistem dan Teknologi Informasi, I(1). 
Nugroho, F. R., Syafei, W. A., \& Somantri, Maman. 2013. Rancang Bangun Aplikasi Streaming Education Pada Perangkat Bergerak Berbasis Android. Transient, II(1), pp. 33-38.

Pratama, Ferdian Aditya. 2014. Penerapan Teknologi Google Cloud Messaging Service Sebagai Pengiriman Push Notification pada Aplikasi Mobile Commerce Berbasis Android. Salatiga: Jurusan Teknik Informatika Universitas Kristen Satya Wacana.

Surendra, M. R. S. 2014. Implementasi PHP Web Service Sebagai Penyedia Data Aplikasi Mobile. ULTIMATICS, VI(2), pp. 85-93.

Widodo, A. W. 2012. Perancangan Aplikasi Mobile Commerce pada Perangkat BlackBerry Menggunakan Framework PhoneGap (Studi Kasus: Butik Emely Shop Semarang). Salatiga: Universitas Kristen Satya Wacana, pp. 2-18. 